\title{
Sportovní trenér: vymezování profese a její rưzné podoby a problémy
}

\author{
Marcela Janíková, Vladimír Jůva, Jan Cacek \\ Masarykova univerzita, Fakulta sportovních studií
}

\begin{abstract}
Abstrakt: Studie je koncipována jako teoretický vhled do profese sportovního trenéra. Na základě kulturně-historické argumentace je jejím cílem nastínit, jak se profese sportovních trenérů utvářela $v$ kontextu dynamicky se rozvíjející oblasti tělesné výchovy a sportu a s jakými problémy je konfrontována. Úvodní část je věnována historickému ohlédnutí (se) za vznikem trenérství. Následně jsou představeny vymezení a charakteristika této oblasti lidské činnosti. $V$ kontextu diskuse o (semi)profesionalismu je zmíněna myšlenka sdíleného profesního prostoru, $v$ němž vedle profesionálních zkušených trenérů působí také dobrovolní a poloprofesionální (začínající) trenéři. Poté jsou v textu rozebírány funkce trenérů a požadavky na jejich kompetence. Výklad ústí do problematiky vzdělávání trenérů. V závěru studie jsou zmíněny tř̌i problémové okruhy trenérské profese: 1) její specifické a obecné charakteristiky, 2) etablování trenérství jako široce pojímané profese, 3) vzdělávání a profesní rozvoj trenérů.
\end{abstract}

Klíčová slova: trenér, trenérství, sport, profese, trenérské vzdělávání, rozvoj trenérství

\section{Sports Coach: Evolving the Profession and Its Various Forms and Challenges}

Abstract: The paper provides theoretical insights into the sports coach profession. Based on cultural-historical argumentation its ambition is to outline, how the sports coach profession evolved in the context of the development of physical education and sport and which problems it faced. The introductory part provides a historical overview of the development of the sports coach profession. In the next step, the evolution of the sports coach profession is outlined. In the context of the debate on semi-professionalism, the phenomenon of shared professional space, where not only professional, experienced coaches but also volunteer and quasi-professional (novice) coaches are working. In the next step, the functions and competencies of sports coaches are discussed. The education of coaches is analysed. By the end of the paper, selected challenges of the sports coach profession and professionalization are addressed: 1) specific and generic features of sports coaches profession; 2) evolving sports coach profession on a broad scale; 3 ) education and professional development of coaches.

Keywords: coach, coaching, sports, profession, coach education, coaching development

Vymezení sociální a pedagogické profese sportovního trenéra je spojeno s komplexní historií lidské civilizace, jejímiž tradičními součástmi jsou pohybová kultura a sport. Jejich antická syntéza $v$ podobě gymnastické výchovy přispěla podporou soutěživosti k rozvoji moderně chápaného sportu a trenérství a současně tělesnou výchovu a sport systematicky propojila se vzdělávacím systémem (s profesí učitele) a s podporou zdraví (pohyb jako lék). 
64 Dnes po celém světě působí miliony trenérů, kteří pomáhají sportovcům všech věkových a výkonnostních kategorií v jejich sportovním i osobnostním rozvoji. Oprávněně se proto rozvoji sportovního trenérství jako profesi věnuje mimořádná pozornost. Výzkumy však poukazují na fakt, že sportovní trenérství dosud nenaplňuje řadu tradičních charakteristických rysů profese. Specifikum trenérství představuje tzv. smíšený model profesní identity, kdy vedle vysokoškolsky vzdělaných profesionálních trenérů působí začínající i dobrovolní trenéři, kteři jsou však pro rozvoj masového sportu nepostradatelní. Rozrůzněnost podob profese sportovního trenéra ústí do diverzity cest, které $\mathrm{k}$ profesi trenérů vedou, a má důsledky pro jejich př́pravné i další vzdělávání.

Studie je koncipována jako teoretický vhled do profese sportovního trenéra. Na základě kulturně-historické argumentace je jejím cílem nastínit, jak se profese sportovních trenérů utvářela $v$ kontextu dynamicky se rozvíjející oblasti tělesné výchovy a sportu a s jakými problémy je konfrontována. $V$ závěru jsou naznačeny vybrané problémové okruhy otevřené do výhledu na profesi sportovních trenérů v budoucnosti.

\section{Vznik a vývoj trenérství}

Globální snahy o konstituování trenérství jako profese jsou markantní zejména od začátku nového milénia. Počátky sociálních aktivit, které vykazují podstatné rysy „trenérstvi““ a kdy především zkušenější jedinci pomáhali mladším, nás však provázejí od vzniku lidské civilizace. Jsou patrně tak staré jako rozvoj specifických pohybových aktivit, které se rozvíjely již v pravěku. Pohybové aktivity, které primárně zajišt'ovaly přežití našich pravěkých předků (hlavně lov a boj), se postupně rozšiřovaly o nové a specifické pohybové formy (např. tance, rituály, iniciace, pohybové hry), jež postupně vytvořily základy tělesné (pohybové) kultury. $V$ rámci jejího rozvoje posléze ve starověku, především v antickém Řecku, vykrystalizoval sport, který měl zpočátku funkci př́pravy $\mathrm{k}$ boji a doprovázení náboženských obřadů (podrobněji viz rozsáhlá literatura $\mathrm{k}$ historii tělesné a pohybové kultury, tělesných cvičení, tělesné výchovy, sportu a olympismu, např. Miller, 2006; Mechikoff, 2010; Grexa \& Strachová, 2011; Lisový, 2015; Kössl, Štumbauer, \& Waic, 2018).

Prvními pravěkými „trenéry“, kteří facilitovali procesy zejména motorického učení, byli pravděpodobně zkušenější jedinci a patrně i nahodilí rádci. Objevuje se zde jeden z podstatných a i v současnosti zdůrazňovaných rysů trenéra, a to „jako ten druhý a více schopný“ (Potrac \& Cassidy, 2006). Učení nových motorických dovedností, jak naznačují pravěké archeologické doklady, např. jeskynní malby, probíhalo hlavně nápodobou.

Se specifickými formami rozvoje sportu se setkáváme ve všech starověkých kulturách. Zejména $v$ souvislosti s novodobým olympijským hnutím se v euroamerické kultuře věnuje nejvíce pozornosti rozvoji tělesné kultury $v$ antickém Řecku. Jeho koncepce gymnastické výchovy jako součásti ideálu kalokagathie přispěla podporou soutěživosti k rozvoji moderně chápaného sportu a trenérství. Antická řecká kultura 
současně tělesnou výchovu a sport systematicky propojila se vzdělávacím systémem

(se školstvím a s profesí učitele) a s podporou zdraví - s počátky zdravotnických a lékařských profesí (Martínková, 2012). Myšlenku zdůrazňující vztah medicíny jako léčby nemocí a gymnastiky, jež vytváři dobré zdraví, najdeme u Platóna. Obdobnou souvislost mezi rozvojem „sportu“, životního stylu a medicínou formuloval Hippokratés, kterého patrně ovlivnil trenér Hérodikos, propojující cvičení s léčbou nemocí (Kouřil, 2017).

S odkazem antické gymnastické výchovy jakožto klíčové součásti starořecké kalokagathie a po staletí klasického vzoru tělesné a sportovní edukace však zároveň vznikala celá řada mýtů, jako např. ideál humanismu či amatérismu i idealizace antických olympijských her (podrobněji Šíp, 2008). Rozvoj olympijských a dalších panhelénských her, jejichž náplní byly vedle sportovních také umělecké soutěže (zevrubně kupř. Wenn \& Schaus, 2007), byl spojen kromě důrazu na systematickou sportovní př́ipravu, $v$ níž nezastupitelnou roli sehrávali trenéři, také se vznikem profesionalizace sportu. $\mathrm{V}$ rámci této tendence se objevily (bohužel pro současný sport velmi časté) počátky negativních jevů (jako např. doping, hostilita či neúměrná glorifikace vítězů) doprovázejících soutěžní (zejména vrcholový) sport.

Antický Řím rozvíjel gladiátorské hry, které svojí brutalitou a ahumánností představují jeden z nejhorších omylů dějin sportu (Strachová \& Grexa, 2014). Současně však docházelo $v$ rámci systematické přípravy gladiátorů $\mathrm{k}$ výraznému posilování významu jejich trenérů a k propojování jejich práce s medicínou. V této souvislosti se připomíná Galénos, působící i jako lékař gladiátorů, jenž analogicky jako řečtí starověcí myslitelé vyzdvihl vztah zdraví a sportu (Kouřil, 2017).

Středověk a tělesná kultura se především spojují s rytířskými ideály a s výchovou světských feudálů (Zeigler, 1993). V rámci edukace směřující k sedmeru rytířských ctností i dalších středověkých „sportovních“ aktivit (např. voltiž, přeskoky, běhy, hody, vrhy, šplh, tanec a hry) působili na dvorech feudálů doboví „trenéři“ - učitelé a mistři. Analogicky jako ve starověkých kulturách postupně docházelo k proměně cílů specifických pohybových aktivit, a to od vojenských k zábavě, lovu pro potěšení, soutěžím a „sportu“. Význam „trenérư“ (učitelů šermu, tance či jezdectví) postupně vzrůstal a týkal se i dalších stavů, hlavně bohatnoucích měšt’anů.

Renesance, navazující na antický odkaz, přichází s novým dưrazem na vztah tělesné výchovy a zdraví, který má být v praxi zajištěn „moderním“ vychovatelem, jenž ve své práci propojuje poslání učitele, „trenéra“, „lékaře“ i rádce (např. Rabelais, 1968). S analogickým komplexním pohledem na vychovatele mladého muže přichází v 17. století Locke (1984). Učitel budoucího úspěšného gentlemana, v intencích vlastní Lockovy pedagogické i lékařské praxe, propojuje výchovně-vzdělávací působení s medicínskými aspekty a „rekreačním sportem“, který tvoří východisko pevného zdraví i osobnostních kvalit podstatných pro život.

Vznik novodobého trenérství souvisí se zakládáním prvních, zejména anglických, sportovních klubů od druhé poloviny 18. století (Day \& Carpenter, 2016). Rozvoj trenérství byl nerovnoměrný a odrážel úroveň a historické tradice jednotlivých sportů. Např́klad v anglických exkluzivních jezdeckých klubech se trenéři systematicky 
66 věnovali bohatým klientům od počátku 19. století (Tomlinson, 2010, s. 94). Obdobně starou historii jako u jezdectví má trenérství šermu. Cíle šermířských škol, jež vznikaly v pozdním středověku, se postupně měnily od zaměření na vojenství a souboje k naplnění „sportovní kratochvíle“ (Roček, 2016, s. 11). I pro současné trenérství je např. zásadní vznik moderní šavlové školy, o kterou se zasloužil proslulý italský mistr Giuseppe Radaelli, jehož systém šermu publikoval již roku 1872 jeho žák Settimo Del Frate (ibid.).

Propojení sportu a školství - trenérství a učitelství, jež koncipovalo antické Řecko, sílilo především od poloviny 19. století na prestižních britských a později i severoamerických středních a vysokých školách. Sportovní soutěže a s nimi spojená systematická př́prava pod vedením trenérů se staly významnou součástí akademického života např. na univerzitách v Oxfordu nebo v Cambridgi (Scambler, 2005, s. 36-37). Sílící pozice sportu na univerzitách v USA (např. Harvard, Princeton nebo Cornell) se odrazila také ve vzniku profesionálního trenérství. Jenkins (2005) připomíná, že roku 1864 začíná pracovat první profesionální kouč právě v rámci severoamerického vysokoškolského sportu.

Především druhá polovina 19. století svými přírodovědeckými objevy ovlivnila rozvoj trenérství založeného na důkazech např. fyziologie nebo medicíny. Tyto tendence zdůraznil vynikající český vědec Jan Evangelista Purkyně (1787-1869), který usiloval o propojení tělesné výchovy ( $v$ intencích současného rekreačního sportu) s vědeckými výzkumy. Cíl medicíny chápal jako podporu zdraví a fyzické zdatnosti, a výrazně tak přispěl k propojování lékařství se sportem i trenérstvím (Novák, 2017). Purkyně, sám aktivní sportovec a nadšený propagátor pohybových aktivit, měl současně blízký vztah k vznikajícímu Sokolu, který trenérství přispěl svým modelem cvičitele orientovaného na tělesný, morální i sociální rozvoj. Takto chápal smysl sportu na přelomu 19. a 20. století zakladatel moderních olympijských her Pierre de Coubertin (1863-1937). Svým zaměřením nejen na vrcholové sportovce, ale na všechny, kteří chtějí sportovat celoživotně, svým důrazem na spolupráci a prátelství i komplexní rozvoj jedince (Jansa et al., 2012, s. 42) vytvořil axiologická východiska současného trenérství.

Podpora sportovního trenérství se po druhé světové válce zaměřila zejména na vrcholový sport, $\mathrm{k}$ jehož rozvoji paradoxně přispěl i nástup studené války na přelomu čtyřicátých a padesátých let minulého století. Elitní sport, např. v rámci olympijských her nebo mistrovství světa, byl jednou z oblastí soutěžení mezi bývalým Sovětským svazem, včetně jeho satelitních států, a USA s jeho spojenci (Day \& Carpenter, 2016). Sportovní trenérství se stále výrazněji opíralo o výsledky výzkumů nejen přírodních, ale i dalších věd (např. psychologie nebo pedagogiky), a postupně se etablovalo ve vznikajících systémech sportovních, kineziologických a kinantropologických věd a stalo se také studijním vysokoškolským oborem.

Společensky nejsledovanější kritérium profesionality a efektivity trenérství v jednotlivých zemích představují úspěchy v mezinárodních sportovních soutěžích. Týkají se sice jen vrcholu dnes široce chápaného trenérství, ale za předpokladu dodržování jasně formulovaných etických požadavků (viz Evropská sportovní charta - Kodex sportovní etiky, 2003; Olympijská charta, 2016; Světový antidopingový kodex, 
2016) jde bezesporu o jedno z klíčových kritérií pro hodnocení úrovně sportovního trenérství v dané zemi. Tento fakt potvrzuje Velká Británie, která se po výrazných sportovních úspěších na počátku 20. století (např. na letních olympijských hrách roku 1900 v Paříži nebo roku 1908 v Londýně, dostupné z https: / www.olympic.org/) postupně propadala na nižší příčky v medailovém pořadí národů (např. 12. pozice na mnichovské olympiádě roku 1972; ibid.). Zásadní obrat nastal na olympijských hrách v Pekingu (2008), kde tým Velké Británie získal 4. místo v tabulce medailí národů, $\checkmark$ Londýně (2012) to bylo již 3. místo a v Riu de Janeiro (2016) dokonce 2. místo za sportovci USA (ibid.). Klíčovým faktorem tohoto úspěchu byl vysoký profesionální standard britského sportovního trenérství (Day \& Carpenter, 2016), které se v posledních dekádách stalo světovým vzorem vědecké a výzkumné, organizačni i informační a především edukační podpory sportovních trenérů.

\section{Vymezení a rysy sportovního trenérství}

Terminologické spojení sportovní trenér/trenérka (nadále budeme používat pouze označení trenér, kdy vycházíme z české odborné literatury, ve které termín trenér označuje muže i ženu) odkazuje na odborníka, jenž instruuje, připravuje, dává hodiny či organizuje sportovní aktivity. V Pedagogické encyklopedii (Lazarová, 2009, s. 438) je trenér zařazen mezi mimoškolní edukátory působící téměř výhradně v rámci sportovní edukace. Pedagogický slovník (Průcha, Walterová, \& Mareš, 2009, s. 316) definuje trenéra jako profesi pedagogického charakteru, která se mj. uplatňuje ve sfére sportu. Kategorie sport se $v$ souvislosti s trenérstvím vymezuje zejména $v$ mezinárodních dokumentech velmi široce, jako formy tělesné činnosti (organizované i neorganizované, individuální i společné), jejichž cílem je rozvoj tělesné i psychické kondice, společenských vztahů, upevňování zdraví a dosahování sportovních výkonů (viz Evropská sportovní charta, 2003; zákon č. 115/2001 Sb., o podpoře sportu). K základním funkcím sportu (v návaznosti na toto široké pojetí sportu) patří upevňování zdraví, výchovná, společenská, kulturní a rekreační (Bílá kniha o sportu, 2007, s. 3). Trenérství následně můžeme vymezit jako pomoc jedincům při naplňování takto chápaného sportu.

Mezinárodní rámec sportovního trenérství (International Sport Coaching Framework, Version 1.2), jenž plní roli celosvětově respektovaného oficiálního dokumentu, trenérství definuje jako „....proces ř́zeného zdokonalování a rozvoje $v$ jednotlivém sportu a v identifikovatelných etapách vývoje“ (ICCE, ASOIF, \& LBU, 2013, s. 14). Uvedené globální vymezení sportovního trenérství současně zdůrazňuje průběžnou vzdělávací a výchovnou podporu trenérů všem účastníkům, tzn. výkonnostním i rekreačním sportovcům. Uvedené charakteristiky sportovního trenérství také podtrhují širši sociální, pedagogickou i zdravotní dimenzi trenérské profese.

Z hlediska typu profese sportovní trenér pracuje:

- primárně s lidmi všech věkových kategorií, s intaktními i znevýhodněnými jedinci (např. jako trenér lehké atletiky či fotbalu); 
68 - s lidmi a se zviřaty (kupř. v jezdectví či v nově se rozvíjejícím dogscooteringu, kdy se sportovec na koloběžce pohybuje společně se psem či psím spřežením);

- hlavně se zviŕraty (např. u agility - sportu pro psy);

- se zviŕaty a roboty (mj. u velbloudích dostihů v arabském světě);

- s věcmi (např. letecké a raketové modelářství zařazené do leteckých sportů);

- z hlediska apelů nejen sportovní etiky by neměl pracovat s kyborgy či mutanty.

Primární role trenérů samožrejmě souvisí s podporou a rozvojem výkonnostních a rekreačních sportovců. Trenéři však současně přispívají sociálnímu rozvoji společnosti utvářením soudržných týmů a budováním společně sdílených zájmů. I na nejvyšších úrovních sportovních soutěží se trenéři vyzývají, aby se zaměřovali na pozitivní sociální interakce a komplexní rozvoj sportovců, a ne pouze na rekordy a výhry (European Commission Sport Unit, 2012). Nezanedbatelné nejsou ani trenérské aktivity zvyšující zaměstnanost, podporující vzdělávání, nákup sportovního vybavení, využívání různých zařízení a areálů či účast na sportovních akcích (Lara-Bercial et al., 2017, s. 12).

Z uvedené primární role sportovního trenéra vyplývá jeho hlavní úkol, který spočívá v zajišt'ování a vedení tréninku sportovce. Sportovní trenér $v$ této souvislosti vykonává činnosti interakční (především na tréninku, soustředěních, závodech či přesunech) a teoretické, jako např. prípravu na tréninky, hodnocení sportovců, sebevzdělávání (Svoboda, 2000). Sportovní trenér pomáhá sportovcům a týmům svými znalostmi, dovednostmi a zkušenostmi při jejich sportovním i osobnostním rozvoji $\checkmark$ jednotě s pravidly fair play (Etický kodex sportovního trenéra ČOV, 2015).

Z legislativního pohledu patří sportovní trenér mezi pedagogické pracovníky (zákon č. 563/2004 Sb., o pedagogických pracovnících a o změně některých zákonů), ale pouze $v$ př́padě, že vykonává přímou pedagogickou činnost. Sportovní pomáhající profese - instruktor sportu a trenér - se objevují také v katalogu prací (nařízení vlády č. 222/2010 Sb., o katalogu prací ve veřejných službách a správě) a v novelizovaném živnostenském zákonu (zákon č. 455/1991 Sb., o živnostenském podnikání, ve znění pozdějších předpisů), kde jsou zařazeny mezi vázané živnosti. Jde zejména o služby $v$ tělesné výchově a sportu a o drezuru zviřat. Tyto vázané živnosti jsou podmíněny odpovídajícím vysokoškolským nebo licenčním vzděláním. Český zákon o podpoře sportu, na rozdíl např. od nového slovenského zákona o sportu (zákon č. 440/2015 Z. z., o športe a o zmene a doplnení niektorých zákonov), jenž se podrobně zabývá vymezením sportovních odborníků i jejich vzděláváním, se trenéry prakticky vůbec nezabývá. Pouze proklamuje jejich podporu v souvislosti se sportem dětí a mládeže a předpokládá evidenci trenérů v rámci vznikající databáze českého sportu (Rejstřík). Trenérská praxe a v ní použivaná označení trenérů jsou však mnohem různorodější, než uvádí česká legislativa. Tuto situaci stručně přibližuje tabulka 1 , která shrnuje nejpouživanější české termíny v oblasti soutěžního, rekreačního a školního sportu. 
Tabulka 1 Používané české termíny a pracovní (profesní) pole trenérů

\begin{tabular}{lll}
\hline \multicolumn{2}{c}{ SPORT (intaktních - znevýhodněných - postižených) } \\
\hline \multicolumn{1}{c}{ soutěžní } & \multicolumn{1}{c}{ rekreační } & \multicolumn{1}{c}{ školní } \\
\hline pomocný, hlavní, reprezentační, ... & instruktor (lyžování, golfu, ...) & trenér \\
trenér (florbalu, požárního sportu, & cvičitel & cvičitel \\
karate,...) & pomahatel (v České obci sokolské) & instruktor \\
kouč (vede zejména sportovní týmy & mistr (tance) & učitel tělesné výchovy \\
v soutěžích) & učitel (bojových umění) & \\
& animátor (sportovních aktivit) &
\end{tabular}

kondiční trenér, ... (pro rekreační - vrcholový sport + různý věk)

Poznámka: Zdroj: vlastní.

Jedním z nejmladších přivlastků, který upřesňuje pole působnosti trenéra, je kondiční. Kondiční trenér (angl. strength and conditioning coach) stejně jako fitness instruktor (angl. exercise instructor) nebo osobní trenér (angl. personal trainer) pracuje s klienty s cílem vyvolat pozitivní změny na různých úrovních fyzické zdatnosti. Kondiční trenér se podle Hoffmana (2011) od osobního a fitness trenéra liší svým primárním zacílením. Zatímco u osobního trenéra a fitness instruktora je typické směřování trenérských aktivit do oblasti korekce zdraví a vybraných aspektů zdatnosti (složení těla, kardiorespirační zdatnost ad.), kondiční trenér cílí na zlepšení pohybových schopností a dovedností, resp. na progresi nebo stabilizaci sportovního výkonu. $Z$ výše uvedeného plyne, že i cílové skupiny populace budou mezi kondičními trenéry, fitness instruktory a osobními trenéry odlišné. Skupinu, s niž pracují kondiční trenéři, tvoří především výkonnostní a vrcholoví sportovci.

$\checkmark$ historickém kontextu bylo vymezení odbornosti kondičního trenéra logickým důsledkem rostoucího pokroku ve vědě a s ním související kvantity informací, které nebylo reálné kapacitně postihnout odborností sportovní (např. basketbalový, fotbalový) trenér. Zajímavým faktem je, že v anglickém názvu odbornosti kondiční trenér (viz výše) se vyskytuje slovo „silový“ (strength). Důraz na silové schopnosti plyne z jejich systémového nadřazení schopnostem ostatním.

Vzdělávání kondičních trenérů je $v$ globálním kontextu velmi různorodé jak z hlediska kvantitativních, tak i obsahových požadavků. Dobrý kondiční trenér by měl dle Hoffmana (2011) absolvovat minimálně bakalářské vysokoškolské vzdělání v oblasti kineziologie ( $v$ České republice mu odpovídá oblast tělesná výchova a sport). Další důležité požadavky na vzdělání kondičních trenérů kalkulují s absolvováním trenérských certifikačních kurzů a procedur. Často zmiňována je i oblast specifických trenérských zkušeností.

$\checkmark$ mezinárodním měřítku existuje mnoho certifikačních agentur, asociací nebo svazů. Pouze jediná vykazuje prakticky univerzální, mezinárodní platnost. Jedná se o certifikaci CSCS (Certified Strength \& Conditioning Specialist), která je zastřešena NSCA (National Strength and Conditioning Association). 
V České republice zajišt’ují vzdělávání kondičních trenérů jednak univerzity v bakalářských a magisterských studijních programech, jednak vzdělávací zařízení (spolky, asociace), které mají akreditovány vzdělávací (rekvalifikační) kurzy v programu Kondiční trenér (uvedeno ve výčtu odborností př̌i MŠMT). Z právního hlediska tak mohou jako trenéři působit jak vysokoškolsky vzdělaní lidé (s patřičnou trenérskou kvalifikací), tak i trenéři, kteři absolvují akreditované vzdělávání v odbornosti Kondiční trenér (rozsah odpovídá studiu trenérství II. tř́idy, tedy minimálně 150 hodin).

Typickými zaměstnavateli kondičních trenérů jsou sportovní kluby, organizace a svazy. Nemalou skupinu tvoři v České republice také kondiční trenéři pracující jako živnostníci v oblasti poskytování tělovýchovných služeb s odborností kondiční trenér. Jak ukazují zahraniční výzkumy (Reverter-Masia et al., 2008; Magnusen, 2010), je při hledání pracovních př́ležitostí v oblasti kondičního tréninku výhodné vlastnit patřičné úrovně certifikací CSCS i diplom z formálního, vysokoškolského vzdělávání, které pozitivně koreluje $s$ výši odměny kondičních trenérů.

$\checkmark$ rámci rozsáhlé analýzy sportovních aktivit Lyle (2002) identifikoval dva hlavní typy (níže v tabulce 2 segmenty) zapojení do sportu: participaci (tzn. rekreační sport - volnočasové sportovní aktivity) a výkon (tj. soutěžní sport). Participace zdůrazňuje zapojení a potěšení ze sportovních aktivit, výkon znamená sportovní konkurenci, soutěže a výsledky. $V$ každém $z$ těchto dvou sportovních segmentů se nacházejí další tři podoblasti. $V$ rámci participace (rekreačního sportu) jde o aktivní zapojení dětí, mládeže i dospělých rekreačních sportovců. Segment výkonu se týká začínajících mladých sportovců (zejména sportovních talentů), výkonnostních a vrcholových sportovců.

Současná koncepce trenérství zdůrazňuje klíčovou orientaci na sportovce (Light \& Harvey, 2017). Její naplnění předpokládá trenérské specializace (současně se zaměřením na konkrétní sport), jež by reflektovaly aktuální potřeby rekreačních nebo soutěžních sportovců $v$ jejich různých fázích sportovní úrovně. Na základě rozdělení sportovních aktivit do dvou hlavních segmentů - participace a výkon (rekreační a soutěžní sport) - navrhuje Mezinárodní rámec sportovního trenérství (ICCE, ASOIF, \& LBU, 2013) šest hlavních trenérských domén (viz tabulka 2). Konkrétní počet a uspořádání těchto trenérských domén se mǔže lišit mezi státy a sporty, které by si

Tabulka 2 Segmenty a domény trenérství1

\begin{tabular}{ll}
\hline Segment participace & Segment výkon \\
Trenérství rekreačního sportu & Trenérství výkonnostního sportu \\
\hline Trenérství dospělých & Trenérství vrcholových sportovců \\
Trenérství mládeže & Trenérství výkonnostních sportovců \\
Trenérství dětí & Trenérství začínajících sportovců \\
\hline
\end{tabular}

Poznámka: Upraveno podle Lara-Bercial et al. (2017, s. 23).

1 S ohledem na současné trendy by se nabízela možnost tabulku 2 obohatit o segment „zdravotních dispozic“ a v případě segmentu „participace“ by bylo možné vyčlenit z dospělých seniory. 
proto měly zpracovat analýzy své personální základny, aby přesně určily kontextuální oblasti a trenérské domény potřebné pro uspokojení potřeb svých sportovců (Lara-Bercial et al., 2017, s. 23).

Uvedené segmenty a domény trenérství ilustrují soudobé, globální a velmi široké vymezení sportovního trenéra (anglicky sport coach), jenž pưsobí nejen v soutěžním sportu (tento užší význam u nás stále převládá - viz tabulka 1), ale pomáhá také rekreačním pravidelným i nahodilým sportovcům ( $v$ rámci sportu pro všechny), kde zvláště respektuje požadavky zdravotního sportu zaměřené zejména na udržení tělesné i mentální zdatnosti.

Trenér dále může pracovat ve školním sportu, tzn. v rámci podpory pohybových a sportovních aktivit organizovaných školou. Významná je $v$ této souvislosti především činnost Asociace školních sportovních klubů České republiky, která iniciuje a podporuje pohybové a sportovní aktivity ve školních sportovních klubech (podrobněji viz https: / / www.assk.cz/). Významné postavení u nás zastávají trenéři v rámci sportovních tříd a sportovních škol, kde se často jejich práce prolíná s profesí učitele tělesné výchovy. Funkce trenéra $v$ této škole mưže mít i charakter učitele tělesné výchovy nad rámec povinných dvou vyučovacích hodin za týden. Dủležitý úkol trenérů ve školách dále souvisí s tvorbou tréninkových plánů pro mimořádně sportovně talentované žáky (státní reprezentant), kteří mají individuální vzdělávací plán. $\checkmark$ běžných školách naopak roli trenéra mnohdy plní učitel tělesné výchovy, např. $v$ rámci sportovních kroužků pořádaných školou po skončení výuky.

\section{Trenér - od semiprofese k profesi?}

Jedním z kličových problémů moderního sportovního trenérství je skutečnost, že vykazuje pouze některé rysy profese, a je proto oprávněně chápáno jako semiprofese (Treutlein, 2001). Se sportovním trenérstvím z pohledu tradičních profesí souvisí celá řada dalších specifik, např. častá absence profesní autonomie trenérů a jejich závislost na laické veřejnosti či skutečnost, že výsledky a hodnocení práce trenéra souvisí především s úspěchy či neúspěchy jeho sportovců (srov. Lazarová \& Uhlířová, 2006; Sekot, 2006; Kocourek \& Kovář, 2014). Trenérům se i v současnosti může stát, že jsou vyměněni za sice dřive úspěšné sportovce, kteří ale nedisponují adekvátním trenérským vzděláním. Náročnou trenérskou práci většinou provází nedostatek času na koncepční práci i další vzdělávání a často (zejména ve vrcholovém sportu) musí trenéři řešit zásadní otázku, zda preferovat potřebný komplexní rozvoj sportovce, nebo jen jeho sportovní úspěchy. Primární orientaci na sportovní úspěchy mnohdy podporuje i systém financování např. sportovních center mládeže.

V souvislosti s problémy profesionalizace sportovního trenérství Mezinárodní rada trenérské excelence (International Council for Coaching Excellence - ICCE), která vznikla $v$ roce 1997 původně pod názvem Mezinárodní rada vzdělávání trenérů (International Council for Coach Education), od počátku formulovala své hlavní poslání $\checkmark$ rozvoji a podpoře sportovního trenérství jako profese. $V$ této souvislosti si ICCE 
72 vytkla i řadu dalších cílů, které s profesionalizací trenérství souvisí, a to podporu: sportu, sportovních hodnot, mezinárodních vztahů a koordinace trenérského vzdělávání; výzkumů trenérství a jejich publikování; inovací trenérského vědění; šíření informací o trenérském kurikulu a kvalifikačních standardech; etického trenérského kodexu; pozitivních vztahů mezi všemi subjekty sportu ad. (podrobněji viz http:// www.icce.ws).

Počáteční úsilí ICCE vyústilo symbolicky v roce 2000 mezinárodním shromážděním zástupců vzdělavatelů trenérů z 29 zemí s cílem zaměřit se na znepokojivé otázky a nové výzvy ve vzdělávání trenérů. Vyústěním tohoto odborného setkání byla Magglingenská deklarace (The Magglingen Declaration, 2000), která formulovala deset ústředních výzev, kterým globálně čelí budoucnost trenérství a vzdělavatelé trenérů:

1. Zřizování a vzdělávání sportovních organizací i jednotlivých trenérů založené na standardech etického chování a vytváření mechanismů pro jejich sledování a dodržování.

2. Identifikace, rozvíjení a evaluace trenérských kompetencí na všech trenérských úrovních.

3. Rozvoj trenérského vzdělávání, které trenérům umožní aplikovat podpůrnou teorii $v$ jejich trenérské praxi takovým způsobem, aby uspokojovali potřeby svých sportovců.

4. Zajištění, aby vlády, sportovní sektor i širší veřejnost poznaly, pochopily a uznaly zásadní roli trenéra v rozvoji sportu na všech úrovních.

5. Přijetí filozofie, která prosazuje a podporuje trenérství orientované na sportovce, vzdělávání cílené na trenéry a profesní rozvoj.

6. Umožnění trenérům, aby měli př́stup a komunikovali s rozvíjejícím se trenérským věděním a dobrou praxí takovým způsobem, který bude podporovat a rozvíjet kontinuální vzdělávání a rozvoj.

7. Rozšiřrení př́stupu k trenérskému vzdělávání a k možnostem profesního rozvoje při zachování kvality jeho poskytování, realizace a výstupů.

8. Rozvoj systémů, které budou podněcovat a podporovat kontinuální vzdělávání a profesní rozvoj trenérů založený na identifikaci a reagování na potřeby jednotlivce.

9. Aktivity zaměřené na rozvoj a získání uznání trenérství jako profese.

10. Rozvoj systémů trenérského vzdělávání, které podporují otevřené učení a umožňují trenérům studovat $v$ době, místě a s četností podle jejich vlastního výběru.

Deklarace vyzvala všechny vládní i nevládní sportovní organizace, Mezinárodní olympijský výbor i národní olympijské výbory, národní a mezinárodní sportovní rídící orgány i vysokoškolské instituce zabývající se trenérským vzděláváním, aby se spojily při řešení problémů trenérského vzdělávání a při naplňování uvedených ústředních výzev.

I přes více než desetileté intenzivní úsilí ICCE i dalších trenérských organizací a institucí zaměěených na zkvalitnění trenérského vzdělávání a profesionalizaci trenérství však globální analýzy ukazují, že sportovní trenérství stále nenaplňuje 
řadu tradičních a charakteristických rysů profese. Především se setkáváme s absencí jasného vymezení účelu, znalostní báze, organizace a etických aspektů sportovního trenérství (Duffy et al., 2011, s. 93).

Jeden z podstatných problémů sportovního trenérství, vzhledem $\mathrm{k}$ jeho profesionalizačním snahám, představuje skutečnost, že se nejen v současné Evropě vyznačuje výraznou variabilitou z hlediska postavení trenérů, jejich prestiže, pracovněprávního zabezpečení i jejich odměňování. Statistické údaje z různých evropských zemí současně dokumentují, že se komunita trenérů - stejně jako u nás - skládá $z$ dobrovolných trenérů, $z$ trenérů na částečný úvazek a profesionálních trenérů. Např́klad ve Velké Británii tvoři 76 \% trenérů dobrovolníci, 21 \% zaměstnanci na částečný úvazek a jen 3 \% jsou zaměstnanci na plný úvazek. Rozdíly v poměru placených $\mathrm{k}$ neplaceným trenérům pak přispívají ke kontrastnímu pohledu na trenérskou identitu (Lara-Bercial et al., 2017).

Zvláště s těmito skutečnostmi pak souvisí hlavní problém trenérství označovaný termínem „smíšený profesní prostor“ (Duffy et al., 2011). Vyjadřuje skutečnost, že $\checkmark$ trenérství, na rozdíl od jiných povolání, vysokým podílem pưsobí - a jsou velmi potřební - dobrovolní trenéři, např. rodiče nebo ještě aktivní sportovci. $\vee$ tzv. smíšeném modelu profesní identity trenérství (viz obrázek 1 ) současně pracuje řada začátečníků či méně graduovaných poloprofesionálních trenérů. Jen několik procent trenérů (přesné údaje o počtech a licencích českých trenérů by měl teprve poskytnout dále zmíněný Rejstř́ik) pak pracuje v pozici profesionálních trenérů.

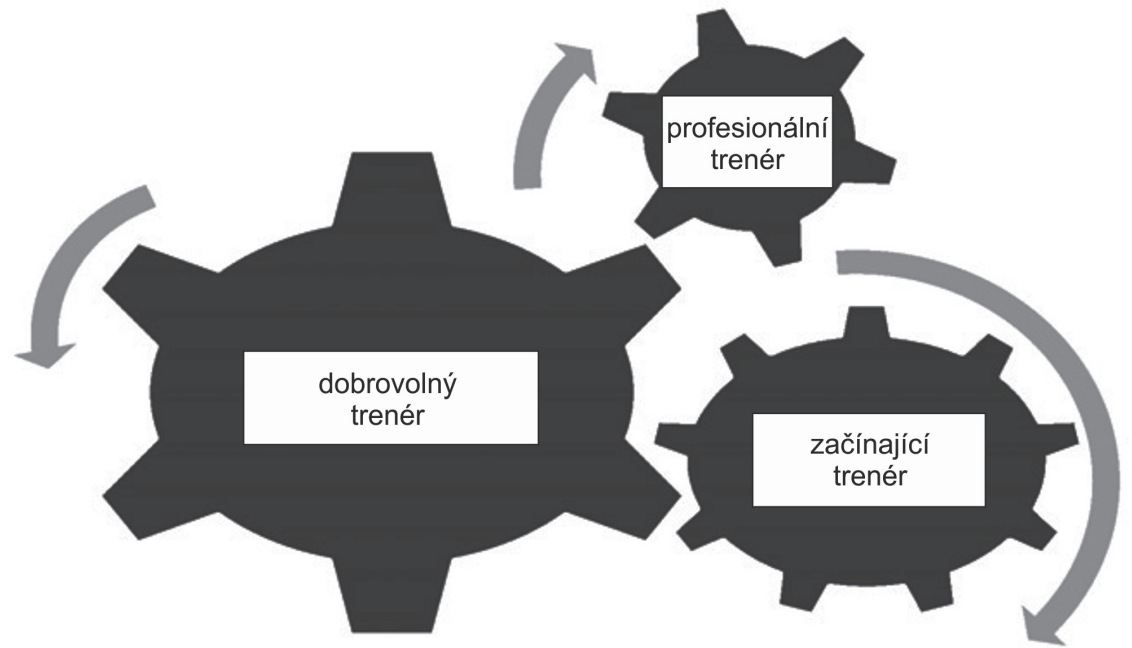

Obrázek 1 Smíšený model profesní identity trenérství. Upraveno podle SASCOC (2011). 
Trenérská profese se ve svých různých podobách realizuje prostřednictvím řady funkcí, pro jejichž naplňování je nezbytné, aby trenéři disponovali odpovídajícími kompetencemi.

Evropský rámec sportovního trenérství specifikoval šest primárních funkcí trenéra (viz obrázek 2), které definují jeho každodenní práci. Tyto primární funkce vznikly na základě konzultací a podrobné analýzy stávající literatury i z aktuálně se rozvíjejícího empirického výzkumu (Lara-Bercial et al., 2017, s. 27):

1. Vymezit vizi a strategii. Trenér $v$ partnerství se sportovci a týmy vytváŕí vizi a strategii založenou na potřebách a stadiu vývoje sportovců a na organizačním a společenském kontextu plánu. Trenér rozvijí konkrétní plán, který nastiňuje kroky potřebné pro uvedení této strategie do života a pro realizaci této vize.

2. Utvářet prostředí. Trenér pracuje se skupinou sportovcủ a přebírá odpovědnost za individuální i institucionální cíle. Za tímto účelem se trenér snaží optimalizovat prostředí, ostatní zaměstnance, vybavení, zdroje a pracovní postupy, a to i prostřednictvím vedení dalších trenérů a pomáhajícího personálu.

3. Budovat vztahy. Trenér buduje pozitivní a efektivní vztahy se sportovci i s dalšími osobami propojenými s plánem. Trenér je zodpovědný za vzájemně se respektující a efektivní pracovní vztahy s odpovědnými osobami (např. s manažery nebo $s$ vedením).

4. Vést praxi, připravovat a řídit soutěže. Trenér organizuje adekvátní a podnětnou praxi za využití efektivních forem a metod podporujících učení a zlepšování. Trenér se připravuje na cílené a vhodné soutěže a také dohlíží a řídí sportovce $v$ těchto soutěžích. Trenér utváří další a relevantní vnitřní a vnější př́ležitosti pro soutěžení, které jsou vhodné k podpoře individuálního a týmového vývoje.

5. Zjistit situaci a reagovat na ni. Trenér pozoruje a vhodně reaguje na události, včetně všech interních i externích vlivů. Efektivní rozhodování je nezbytné pro plnění této funkce a představuje schopnost, která by se měla rozvíjet u všech trenérů v každé fázi jejich vývoje.

6. Reflektovat a učit se. Trenér hodnotí tréninky i soutěže jako celek a neustále hledá zlepšení. Navíc osobní hodnocení a reflexe podporují proces průběžného učení a profesního rozvoje. Důležitým prvkem tohoto procesu je úsilí trenéra podporovat vzdělávání a rozvoj dalších trenérů (Lara-Bercial et al., 2017, s. 28).

Uvedené primární funkce trenéra se vzájemně determinují a směřují k permanentnímu zlepšování trenérské práce (viz obrázek 2).

$\checkmark$ souvislosti se specifičností trenérských rolí a vnějších i vnitřních podmínek mohou mezi trenéry existovat určité rozdíly $\vee$ naplňování jednotlivých funkcí. Zkušení trenéři se na rozdíl od začínajících většinou zabývají všemi funkcemi. „Východisko tohoto uceleného souboru trenérských funkcí tvoří zřetelný a silný soubor hodnot, přesvědčení, pevné vize a strategie, které vycházejí z cílů sportovců, týmu a organizačního i institucionálního kontextu." (Lara-Bercial et al., 2017, s. 29) 


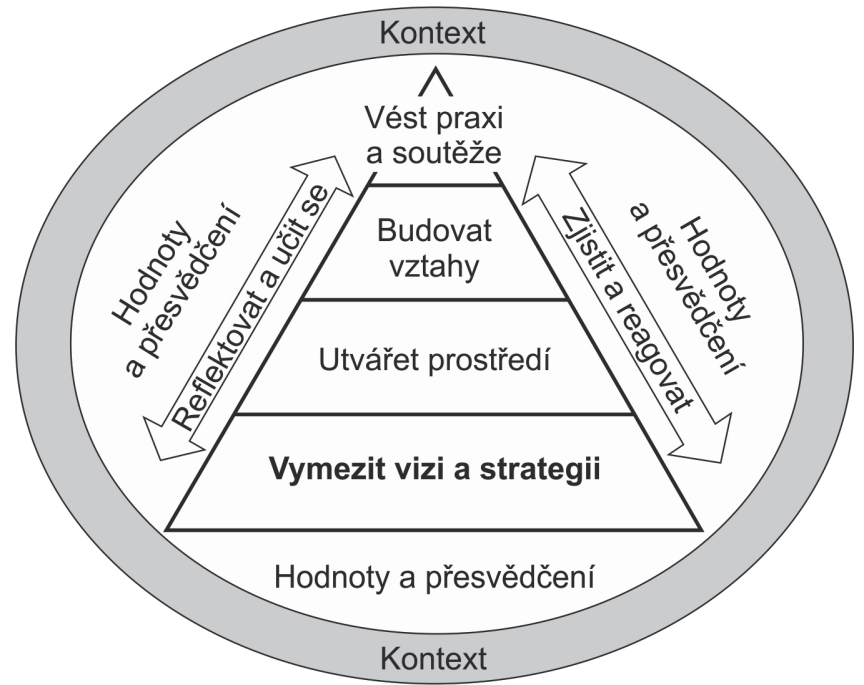

Obrázek 2 Primární funkce trenéra. Upraveno podle Lara-Bercial et al. (2017, s. 29).

Naplňování jednotlivých funkcí souvisí rovněž s tím, jakými kompetencemi trenéři disponují a do jaké míry jsou u nich tyto kompetence rozvinuty. Trenérská kompetence je pojímána jako souhrn způsobilostí, jež podmiňují úspěšnou, resp. efektivní práci trenéra. Toto obecné vymezení zohledňuje skutečnost, že trenéři operující $\checkmark$ různých segmentech a doménách (srov. tabulku 2) potřebují mít (a mají) do jisté míry odlišné kompetence. Dále proto představíme vybrané kompetenční modely na obecnější úrovni, nebot' není v možnostech tohoto textu rozlišit je ve vztahu k různým segmentům a doménám trenérství.

S ohledem na genezi kompetencí se rozlišují kompetence, resp. jejich základy, vrozené, které jsou však v praxi v souvislosti se sportovními úspěchy často přeceňované, a získávané, zejména na základě výzkumů, studia, praxe a reflexe. Obsahově lze kompetence dělit s ohledem na „obor“ ( $v$ př́padě trenérů konkrétní sport) na interakci rozvíjející se na mnoha úrovních a na osobnost.

Do klíčových trenérských kompetencí se řadí organizace a evidence, komunikace a kooperace, řizení a vedení, aplikace oborově didaktických dovedností, koučování a psychologické aspekty práce (Kováŕ \& Zemanová, 2009).

Zahraniční zdroje - inspirativně např. Schierz, Thiele a Fischerová (2006) - vymezují v kontextu svého přístupu (vzdělávání trenérů založeného na případech) čtyři oblasti specifických trenérských kompetencí:

1. Systémová kompetence - spadá do ní adekvátní jednání v daných systémech (např. v systému vrcholového výkonnostního sportu jde o vztahy s kooperujícími institucemi, jako jsou svazy, podpůrné struktury). Pro trenéra z toho vyplývá úloha tyto systémy poznávat, analyzovat a využívat. Kromě toho se trenér dostává do kontaktů s dalšími volněji propojenými systémy (škola, média, politika...), mezi ni- 
76 miž musí mnohdy naplňovat zprostředkující funkci, popř. je musí ovlivňovat či řídit. $\checkmark$ př́padech kolize mezi zájmy sportovce a nároky systému vrcholového výkonnostního sportu má být trenér schopen jednat i proti systému.

2. Věcná kompetence - zahrnuje schopnosti trenérů jednat účelně, přiměřeně a důsledně s ohledem na obsahové (věcné) požadavky tréninkové situace (účelně znamená s dosahováním žádoucích výsledků, přiměřeně značí s ohledem na předpoklady sportovce, na strukturu tréninku a na komplexnost podmínek jednání).

3. Sociální kompetence - reprezentuje schopnost trenérů jednat srozumitelně a odpovědně. Srozumitelně znamená, že se trenéři vyjadřují jednoduše a precizně. Řečové projevy mají mít jasný rád a mají navíc pưsobit stimulačně. Nonverbální složka komunikace má verbální podporovat. Kromě toho jde o trenérovu schopnost naslouchání a empatie. Odpovědné jednání znamená, že si je trenér vědom efektů, které jeho činnost má na sportovce. Zahrnuje to i schopnost zaujímat perspektivu jiných. Součástí je zohledňování společenských hodnotových představ o mezilidském jednání.

4. Osobnostní kompetence - vztahuje se $\mathrm{k}$ jednání trenéra vưči sobě samému a promítá se do vazeb na tři předešlé skupiny kompetencí. Trenér projevuje osobnostní kompetenci, když vnímá komplikované vlivy systému, obsahu a sociálního spolubytí ve vztahu ke svému osobnímu jednání a promítá je do důsledků pro své kompetence ve všech třech oblastech (Schierz et al., 2006, s. 96-98).

Vedle toho jsou $v$ odborné literatuře popsány také specifické trenérské kompetence zaměřené na soutěžní sport (Lara-Bercial et al., 2017). Hlavní oblastí práce trenéra je zde vedení sportovce (družstva) v prípravě a soutěži. Cílem je rozvoj výkonnosti sportovců a celkový rozvoj jejich osobnosti. Trenér by měl být kompetentní $\mathrm{k}$ těmto základním oblastem:

1. Interpersonální, která zahrnuje prostředí (např. kultura sportu, vláda, kluby, škola, asociace, rodiče, média), vztahy (kupř. komunikace, empatie, umění naslouchat, koučování - osobní rozvoj, znalost prostředí daného sportu včetně týmů, proti/ hráčů), metodiku (mj. plánování, organizování, řizení, vytvoření pozitivního klimatu, pozorování, zpětná vazba, evaluace, demonstrace, instruktáž).

2. Profesní, do níž patří znalost sportu (např. tenis) od pravidel, přes techniku, taktiku, přislušenství, vybavení...; znalost sportovců (jejich dovednosti na každém stupni jejich rozvoje, motivování); sportovní - oborové znalosti, jejichž součástí je motorický rozvoj, biomechanika, fyziologie, výživa, první pomoc, bezpečnost, antidoping, management, pedagogika sportu, psychologie...; základní dovednosti (mj. znalost jazyka, matematika).

3. Intrapersonální, k níž řadíme filozofii trénování - identitu, víru - důvěru, styl vedení... a využití svých zkušeností v roli sportovce (autonomie, odpovědnost, sebereflexe, kritické myšlení ...). 


\section{Trenérské vzdělávání}

Kazuistiky vynikajících sportovních trenérů dokumentují, že jejich profesní výkon ovlivňuje řada determinant (např. Jones, Armour, \& Potrac, 2004). Patř́ k nim bezesporu významná, ale v praxi mnohdy přeceňovaná, vlastní sportovní dráha. Ta bývá společně se zkušenostmi s vlastními trenéry primárním zdrojem sportovní empirie. Profesní rozvoj sportovního trenéra dále význačně determinují okolnosti vstupu do trenérské profese, vlastní trenérská praxe a kvalita absolvovaného trenérského vzdělávání.

Vzdělávání sportovních trenérů vymezují Trudel a Gilbert (2006, s. 516) jako proces, v němž se budoucí (popř. současní) trenéři učí trénovat. Oficiální koncepce trenérského vzdělávání tradičně obhajovaly především význam formálních programů, které podporují výraznou vědeckou a profesní trenérskou orientaci (Duffy et al., 2011). Systematické, formální trenérské vzdělávání, jehož cílem je mj. získání trenérské licence (trenérské třídy), nejčastěji zajišt’ují celostátní programy, sportovní svazy nebo sportovní vysoké školy.

Vývoj českého formálního trenérského vzdělávání shrnuje Kovář (2011). Jako jeho základní mezníky uvádí zařazení trenérského vzdělávání na vysoké školy v roce 1953, vznik Jednotné kvalifikace tělovýchovných kádrů Československého svazu tělesné výchovy v roce 1963 a zrušení systému jednotných sportovních kvalifikací roku 1993. Dovalil (2014) dokumentuje konkrétní proměny kurikula trenérského vzdělávání na přikladu Trenérské školy Fakulty tělesné výchovy a sportu Univerzity Karlovy od jejího založení v roce 1953 po současnost. Aktuálně se inovacím formálního trenérského vzdělávání věnovaly zejména nové akreditace trenérství ( $v$ rámci studia tělesné výchovy a sportu) na českých sportovních fakultách v Praze, Olomouci a Brně.

$\checkmark$ celosvětovém měřitku se vymezením kurikula formálního trenérského vzdělávání zabývá od svého vzniku Mezinárodní rada pro trenérskou excelenci (International Council for Coaching Excellence - ICCE), která zpracovala mj. standardy vysokoškolského bakalářského trenérského vzdělávání (poslední verze z ř́jna 2016 - podrobněji viz http://www.icce.ws).

Koncepci především formálního trenérského vzdělávání v rámci Evropské unie významně ovlivnil od roku 2002 projekt AEHESIS (Aligning a European Higher Education Structure in Sport Science - Sladění struktury evropského vysokoškolského vzdělávání ve vědě o sportu). Jeho závěrečná zpráva mj. předložila podrobně rozpracovaný návrh kurikula bakalářského trenérského vzdělávání (Petry, Froberg, \& Madella, 2006). Jako součást projektu AEHESIS vznikl Evropský rámec pro uznávání trenérských kompetencí a kvalifikací (The European Framework for the Recognition of Coaching Competence and Qualifications - EFRCCQ). Evropská rada trenérství (European Coaching Council - ECC, kontinentální sekce ICCE) tento rámec přijala $v$ roce 2007 , a zahájila tak proces modernizace vzdělávání evropských trenérů a současně vytvořila předpoklady pro koordinaci s obecnými evropskými vzdělávacími koncepcemi, jako je Evropský kreditový systém (European Credit Transfer and Accumulation System - ECTS) a Evropský rámec kvalifikací pro celoživotní učení (European Qualifications Framework for Lifelong Learning - EQF). Evropský rámec 
78 pro uznávání trenérských kompetencí a kvalifikací zejména zdůraznil potřebu přechodu od kvalifikace vymezené absolvovaným počtem výukových hodin a získanými znalostmi z jednotlivých předmětů $\mathrm{k}$ pojetí kvalifikace charakterizované výstupy z učení, tzn. zaměřené na rozvoj dovedností a kompetencí potřebných pro výkon specifických pracovních míst (Lara-Bercial et al., 2017, s. 13).

Na problematiku trenérského vzdělávání se v posledních dekádách zaměřila řada empirických výzkumů (např. Cushion, Armour, \& Jones, 2003; Lemyre, Trudel, \& Durand-Bush, 2007; Jiménez \& Lorenzo, 2009; Duarte \& Culver, 2014; Crisp, 2018). Jejich závěry konstatují, že formální (licenční) vzdělávací programy tvoří pouze jednu z mnoha príležitostí, kdy se trenéři učí trénovat. Primární zdroje profesního vědění trenérů tvoři vlastní a kriticky reflektovaná sportovní a trenérská empirie a pozorování ostatních trenérů. Vedle formálního trenérského vzdělávání jsou proto podstatné takové aktivity, jako je např. mentoring nebo diskuse s kolegy ve sportu. Na vzdělávání trenérů se současně musí aktivně podílet vedle sportovních svazů, škol a asociací také samotné sportovní kluby a nejrůznější sportovní centra a střediska. V rámci tohoto „klubového“ vzdělávání je především kličová podpora mentoringu, kdy zkušení trenéři předávají své znalosti mladším kolegům. Armourová (2011) dále zdůrazňuje, že pro efektivitu trenérského vzdělávání je zároveň důležité, pokud trenéri dokážou $v$ rámci svého vzdělávání spolupracovat a sdílet informace s ostatními kolegy. $\mathrm{K}$ podstatným zdrojům informálního učení sportovních trenérů $v$ současnosti stále častěji patři textové a obrazové informace a zejména videa umístěná na internetu (Koh, Lee, \& Lim, 2018).

Zdá se však, že i nadále ve vzdělávání sportovních trenérů převládá spiše transmisivně koncipované formální vzdělávání. Tuto přetrvávající situaci potvrzuje také Kovář (2011) ve své analýze českého trenérského vzdělávání. Uvádí, že převažuje spiše jeho pasivní a encyklopedické pojetí založené na znalostech: „Neformální vzdělávání trenérů není dosud $v$ ČR zcela rozvinuto, není zatím vyžadováno sportovními svazy a organizacemi, ale jeví se jako potřebné." (Kovář, 2011, s. 14)

V profesní gradaci sportovních trenérů sehrává vedle formálního vzdělávání stále významnější úlohu vzdělávání neformální a informální (Martens, 2006; Nelson, Cushion, \& Potrac, 2006; Lyle et al., 2009; Mallett et al., 2009). Týká se všech forem a metod organizovaného i individuálního a samostatného trenérského vzdělávání a učení, které probíhá mimo rámec formálního vzdělávání, tzn. zejména mimo trenérské kurzy zaměřené na získání trenérské licence.

Neformální trenérské vzdělávání je typické organizovanými vzdělávacími nabídkami, které pro trenéry připravují např. sportovní svazy nebo sportovní fakulty. $Z$ těchto nabídek převládají kratší i vícedenní semináře, přednášky sportovních odborníků, workshopy, popř. odborné konference a další organizované vzdělávací aktivity. Vybrané sportovní svazy současně po svých trenérech oprávněně požadují absolvování neformálních vzdělávacích aktivit jako předpoklad pro zahájení dalšího vyššího licenčního (formálního) vzdělávání (např. systém doškolování Fotbalové asociace České republiky - podrobněji viz https://trenink.fotbal.cz/). 


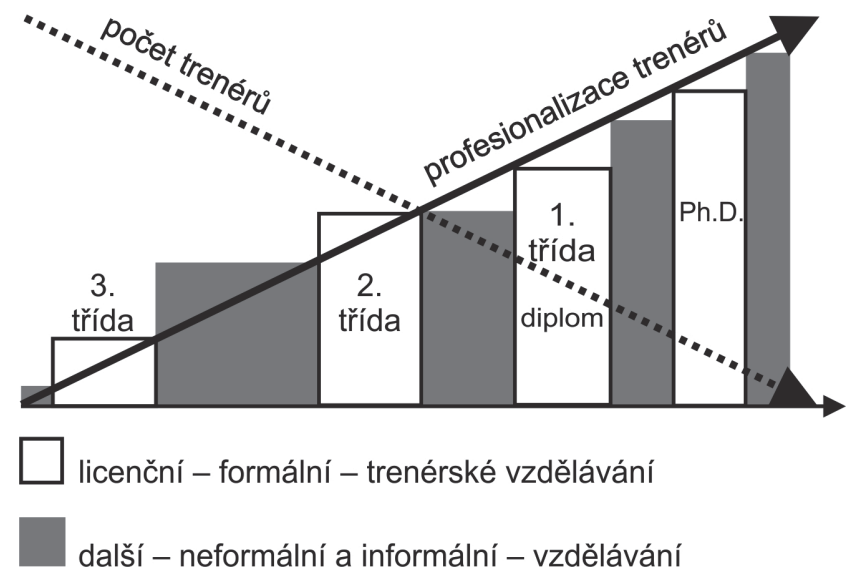

Obrázek 3 Gradace a formy trenérského vzdělávání. Zdroj: vlastní.

Gradace vzdělávání sportovního trenéra představuje velmi komplexní a dlouhodobý proces. Trenér by $v$ něm měl vedle absolvování formálních trenérských kurzů, zakončených získáním trenérské licence, využívat rozšiřující se nabídky neformálního trenérského vzdělávání doplněnou každodenním informálním učením. Obrázek 3 schematicky ilustruje potřebné prolínání trenérského licenčního (formálního) vzdělávání (od získávání nejnižších trenérských tř̌́d až po vědecký titul v oboru kinantropologie nebo věd o sportu) s neformálním a informálním vzděláváním a učením sportovních trenérů. Obrázek 3 zároveň ukazuje jednu z klíčových cest směřujících $\mathrm{k}$ profesionalizaci sportovních trenérů.

Jak jsme již uvedli, v České republice trenérské vzdělávání organizačně zajišt’ují především tzv. trenérské školy na sportovních fakultách ve spolupráci se sportovními svazy. Sportovní fakulty většinou garantují tzv. společný vědecký základ sportovního tréninku, který obsahuje např. problematiku sportovní fyziologie, teorie sportovního tréninku, psychologie či pedagogiky sportu. Sportovní svazy následně zajišt'ují vzdělávání v konkrétních sportovních specializacích, včetně (různým způsobem organizované a reflektované) trenérské praxe a mentoringu.

Podmínky pro přijetí do trenérského vzdělávání tvoří maturita, kterou lze nahradit kurzem $v$ rámci trenérské školy, získaná nižší trenérská licence (tř́ída) a většinou také doporučení sportovního svazu (spolku). $V$ některých sportech je současně požadována vlastní trenérská praxe a doložené další (neformální) trenérské vzdělávání. $\checkmark$ České republice převládá tř́stupňové trenérské vzdělávání, v některých sportech pak čtyřstupňové. Obecná a globálně podporovaná tendence směřují k pěti úrovním. Rozsah a obsah jednotlivých úrovní trenérského vzdělávání je u nás, na rozdíl od situace např. v USA nebo Velké Británii, vymezen pouze rámcově. Pro 3. trenérskou tř́́du (licence C) jde o nutných 50 výukových hodin, u 2. tř́dy (licence B) 150 hodin (200 hodin v prípadě kurzu doplňujícího maturitu), 1. třída (licence A) předpokládá 
80 vysokoškolské, nejčastěji kombinované studium v trvání 4 semestrů (zhruba 500 hodin). Ukončení trenérského vzdělávání většinou bývá formou ústní zkoušky, vypracování závěrečné práce (od 2. trenérské třídy) a „pedagogického výstupu“. Platnost udělené trenérské licence je také různá podle daného sportu.

V rámci formálního, neformálního i informálního trenérského vzdělávání jsou podstatné procesy učení samotných trenérů. Werthnerová a Trudel (2006) vymezili typické tzv. situace učení sportovních trenérů (viz obrázek 4) a zdůraznili, že v praxi trenérského vzdělávání nedochází k výrazné polarizaci mezi situacemi řízeného učení (zejména v rámci formálních trenérských kurzů) a neřízeným učením (např. při diskusích s dalšími kolegy). Současně zdůraznili význam reflexe za využití kvalitních učebních materiálů, tj. externích zkušeností, nebo interní zkušenosti, tzn. empirie, která již tvoří kognitivní strukturu učícího se trenéra. Respektování významu, který sehrávají všechny tři typy situací učení uvedené na obrázku 4, by mělo ovlivnit náš tradiční způsob rozvoje trenérského vzdělání. Úsilí by mělo zvláště směřovat k rozvoji materiálů pro trenéry, které jsou pro ně relevantní, a zajistit, aby je efektivně distribuovali kvalifikovaní učitelé a instruktoři. Facilitace situací nepř́mého učení pro trenéry je méně zřejmá, a přesto důležitá. Trenéři i jejich vzdělavatelé by si měli uvědomit, že situace nepřímého učení nemusí být vždy náhodné: „Trenéři mohou sami vyhledávat, a dokonce vytvářet tyto situace, a sportovní organizace by je měly v těchto aktivitách podporovat.“ (Werthner \& Trudel, 2006, s. 209)

Globální analýzy trenérského vzdělávání, iniciované především Mezinárodní radou pro trenérskou excelenci a jejím Evropským výborem pro trenérství (International Council for Coaching Excellence, European Coaching Council), dokumentují přetrvávající problémy, se kterými se setkáváme také u nás. Ukazuje se, že v klíčových institucích, které zabezpečují trenérské vzdělávání, chybí dostatečné zdroje. $\checkmark$ některých zemích a sportovních federacích mají nízkou prioritu rozvoj a podpora

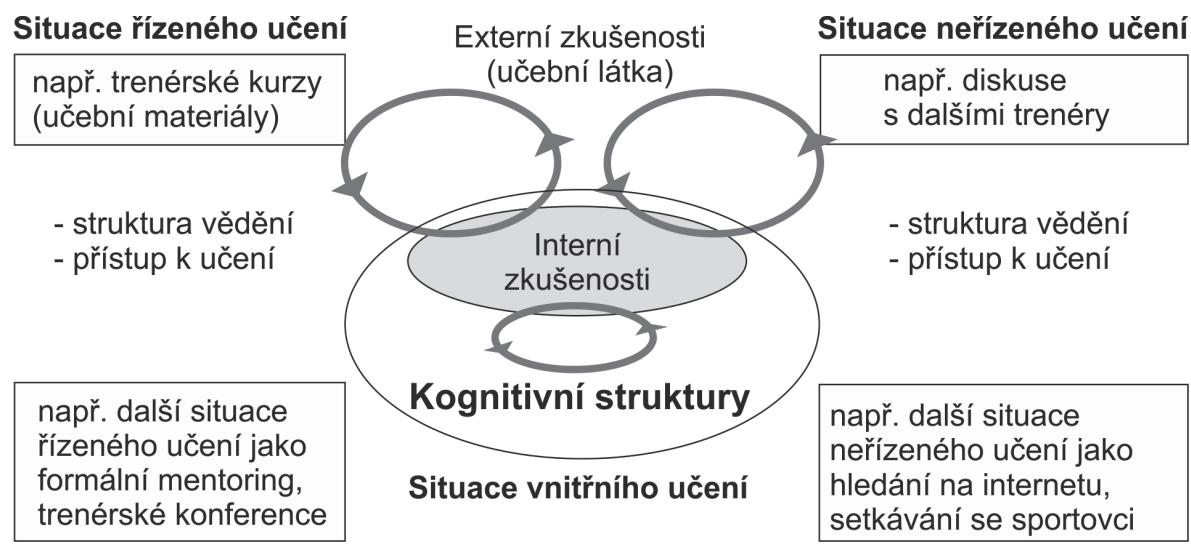

Obrázek 4 Různé situace učení sportovních trenérů. Upraveno podle Werthnerová a Trudel (2006, s. 202). 
kvalifikovaných pracovníků, kteří vzdělávání trenérů zabezpečují. Z didaktického

hlediska nebývá trenérské vzdělávání dostatečně prakticky zaměřeno a pouze malý prostor se věnuje zkušenostnímu učení. Nevyřešené otázky souvisí s uznáváním trenérského i dalšího vzdělávání, dosaženého rưznými cestami, a s hodnocením a platností trenérských licencí (Lara-Bercial et al., 2017, s. 15).

\section{Vybrané problémy}

Globální společenská i výzkumná pozornost věnovaná současnému sportovnímu trenérství ukazuje, že tato relativně mladá profesní oblast nastoluje celou řadu nových otázek, dilemat a problémů.

Patří k nim např́klad otázka, co je na trenérství jedinečné a co má společného $s$ dalšími profesemi. Trenérství se od svého vzniku primárně orientuje na práci s lid$\mathrm{mi}$, kterým pomáhá $\mathrm{v}$ dnes velmi široce chápaném sportovním rozvoji a současně na jejich cestě životem. Pomáhající a sociální profese sportovního trenéra je tradičně zaměřena na péči o vzdělávání a svým charakterem (bohužel jen v některých př́padech i legislativně) se řadí mezi pedagogické profese. $V$ současnosti se mimořádný důraz (podobně jako $v$ antice či renesanci) klade na význam sportu v péči o fyzické i mentální zdraví. $O$ benefity pohybových a sportovních aktivit, které se opakovaně i v nových souvislostech empiricky potvrzují, se opírají základní sportovní dokumenty a trenérská kurikula. Výzvy $\mathrm{k}$ užší vědecké a především praktické kooperaci sportu a lékařství se pozitivně odrážejí např. v úspěšném celosvětovém programu Cvičení je lék. Uvedený a dnes již desetiletý program konkrétně ilustruje prohlubující se vztah mezi lékařem, jenž předepisuje „pohyb jako lék“, a trenérem (zejména rekreačním nebo kondičním), který - na základě svého kvalitního a celoživotního vzdělávání tento „lék“ vhodně aplikuje. Aktivity sportovního trenéra se však stále častěji zaměřují vedle interakce s lidmi i na sporty se zviŕaty. Tato situace si patrně vyžádá hlubší spolupráci trenérství s dalšími obory, jako je např. veterinární lékařství, etologie, animal welfare, hipologie, psychologie koní, přirozená komunikace nebo kynologie.

Mezi dalši problémy patři etablování sportovního trenérství jako široce pojímané profese. Dnešní široké vymezení sportu (od rekreačního pro všechny až po vrcholový profesionální sport reflektující nejnovější vědecké výzkumy) se odráží v profesní specifice trenérství. Jde o „smíšený profesní prostor“, jenž respektuje a deklaruje významnou a nezastupitelnou roli také začínajícím, pomocným, dobrovolným či poloprofesionálním trenérům vedle trenérů profesionálních. Ukazuje se, že je $v$ této souvislosti významná nejen další profesionalizace trenérů pracujících na plný úvazek, mj. vycházející (analogicky jako u tradičních profesí) z pregraduálního a zejména dalšího vzdělávání směřujícího $k$ trenérské excelenci. Stejně důležitá je podpora profesní identity i „neprofesionálních“ trenérů, opírající se o rozvoj kvalitního a především neformálního vzdělávání a o etické trenérské kodexy. Ty se zatím u nás týkají spíše jen špičkových trenérů, ale měly by (podobně jako ve Velké Británii nebo v Německu) podpořit profesní autonomii celého spektra sportovních trenérů. 
82 Otázkou hodnou zvláštního zřetele jsou genderové nerovnosti v trenérství, které se prozatím profiluje jako typicky mužská doména.

Jak je z výše uvedeného patrné, klíčovou úlohu zde sehrává vzdělávání a profesní rozvoj trenérů. $\mathrm{S}$ tím je spojena celá řada otázek. Na jedné straně se setkáváme s globálním a legitimním úsilím o nalezení společného rámce trenérství a trenérského vzdělávání. Současně však sílí snahy o vymezení a s tím související specifickou prípravu trenérů orientovaných nejen na rưzné sporty, ale zároveň i na další tělovýchovné aspekty (soutěžní nebo rekreační sport, různé věkové skupiny sportovců, intaktní nebo postižení sportovci či klienti atd.). Trenérské vzdělávání bude muset $v$ této souvislosti patrně vycházet $z$ hlubšího propojení nejen s řadou pedagogických nebo zdravotnických profesí, ale třeba se i více opírat o chovatelství a ošetřovatelství zviřat. Vzniká tak problém, jak do přeplněného kurikula trenérského vzdělávání integrovat nové a aktuální oblasti související např. s poradenstvím, sociální prací, rekreologií, cestovním ruchem, balneologií či zooterapií. Vhodně koncipované vzdělávání a podpora profesního rozvoje trenérů je zásadním předpokladem kvality jejich profesního výkonu a rozhodujícím momentem jejich profesionalizace.

\section{Literatura}

Armour, K. (Ed.). (2011). Sport pedagogy: An introduction for teaching and coaching. Harlow: Pearson.

Bílá kniha o sportu. (2007). Lucemburk: Úřad pro úřední tisky Evropských společenství.

Crisp, P. (2018, May 17). Sports coach mentoring - Impacts on the mentors, not the "mentees". A case study of the active Sussex coach support officers scheme. Sport Journal, 20. Dostupné z http: / / thesportjournal.org/article/sports-coach-mentoring

Cushion, C. J., Armour, K. M., \& Jones, R. L. (2003). Coach education and continuing professional development: Experience and learning to coach. Quest, 55(3), 215-230.

Day, D., \& Carpenter, T. (2016). A history of sports coaching in Britain: Overcoming amateurism. London: Routledge.

Dovalil, J. (2014). Trenérská škola fakulty tělesné výchovy a sportu. In L. Flemr, J. Němec, \& O. Novotný (Eds.), Pohybové aktivity ve vědě a praxi: konferenční sborník u príležitosti 60. výročí založení Fakulty tělesné výchovy a sportu Univerzity Karlovy v Praze (s. 339-352). Praha: Karolinum.

Duarte, T., \& Culver, D. M. (2014). Becoming a coach in developmental adaptive sailing: A lifelong learning perspective. Journal of Applied Sport Psychology, 26(4), 441-456.

Duffy, P., Hartley, H., Bales, J., Crespo, M., Dick, F., Vardhan, D., Nordmann, L., \& Curado, J. (2011). Sport coaching as a „profession“: Challenges and future directions. International Journal of Coaching Science, 5(2), 93-123.

Etický kodex sportovního trenéra ČOV. (2015). Dostupné z https: / /www.olympic.cz/text/107--eticky-kodex-sportovniho-trenera

European Commission Sport Unit. (2012). EU guidelines on dual careers of athletes. Brussels: European Commission.

Evropská sportovní charta; Kodex sportovní etiky. (2003). Praha: DISRE.

Grexa, J., \& Strachová, M. (2011). Dějiny sportu: Přehled světových a českých dějin tělesné výchovy a sportu. Brno: MU.

Hoffman, J., \& American Kinesiology Association. (2011). Careers in sport, fitness, and exercise. Champaign: Human Kinetics. 
ICCE, ASOIF, \& LBU. (2013). International framework for coaching - version 1.2. Champaign: Human Kinetics.

Jansa, P., Jůva, V., Kocourek, J., Svozil, Z., \& Kovář, K. (2012). Pedagogika sportu. Praha: Karolinum.

Jenkins, S. P. R. (2005). Sports science handbook. Essex: Multi Science Publishing.

Jiménez, S., \& Lorenzo, A. (2009). El mentoring como medio formativo en la educación del entrenador de baloncesto. Revista Internacional de Ciencias del Deporte, 15(5), 36-45.

Jones, R. L., Armour, K. M., \& Potrac, P. (2004). Sports coaching cultures: From practice to theory. London: Routledge.

Kocourek, J., \& Kovář, K. (2014). Trenérství. In P. Jansa, V. Jůva, J. Kocourek, Z. Svozil, \& K. Kováŕ, Pedagogika sportu (s. 165-195). Praha: Karolinum. Koh, K. T., Lee, T. P., \& Lim, S. H. (2018). The internet as a source of learning for youth soccer coaches. International Journal of Sports Science \& Coaching, 13(2), 278-289.

Kössl, J., Štumbauer, J., \& Waic, M. (2018). Kapitoly z dějin tělesné kultury. Praha: Karolinum.

Kouřil, J. (2017). Historický pohled na zdraví z pohledu antiky. In M. Blahutková (Ed.), Pohybový aparát a zdraví (s. 9-21). Brno: Paido.

Kovář, K. (2011). Současné trendy ve vzdělávání trenérů. Česká kinantropologie, 15(3), 11-16.

Kováŕ, K., \& Zemanová, L. (2009). Koncentrace pozornosti jako předpoklad výkonu v triatlonu. Česká kinantropologie, 3(3), 75-85.

Lara-Bercial, S., North, J., Hämäläinen, K., Oltmanns, K., Minkhorst, J., \& Petrovic, L. (2017). European sport coaching framework. Champaign: Human Kinetics.

Lazarová, B. (2009). Mimoškolní edukátoři. In J. Průcha (Ed.), Pedagogická encyklopedie (s. 436-441). Praha: Portál.

Lazarová, B., \& Uhlířová, V. (2006). Osobnost trenéra: K některým profesním požadavkům. In Kolektiv autorů, Sborník prací fakulty sportovních studií, I. ročník: Sport jako sociálně-kulturní fenomén (s. 31-48). Brno: MU.

Lemyre, F., Trudel, P., \& Durand-Bush, N. (2007). How youth sport coaches learn to coach. Sport Psychologist, 21(2), 19-209.

Light, R. L., \& Harvey, S. (2017). Positive pedagogy for sport coaching. Sport, Education and Society, 22(2), 271-287.

Lisový, I. (2015). V zemi mudrců a olympijských vítězů: Každodenní život dávných Řeků školství, výchova, sport a hry. Ostrava: Repronis.

Locke, J. (1984). O výchově: výbor z díla. Praha: SPN.

Lyle, J. (2002). Sport coaching concepts: A framework for coaches' behaviour. London: Routledge.

Lyle, J., Mallett, C. J., Trudel, P., \& Rynne, S. B. (2009). Formal vs. informal coach education: A response to commentaries. International Journal of Sports Science \& Coaching, 4(3), 359-364.

Magnusen, M. J. (2010). Differences in strength and conditioning coach self-perception of leadership style behaviors at the National Basketball Association, division IA, and division II levels. The Journal of Strength \& Conditioning Research, 24(6), 1440-1450.

Mallett, C. J., Trudel, P., Lyle, J., \& Rynne, S. B. (2009). Formal vs. informal coach education. International Journal of Sports Science \& Coaching, 4(3), 325-334.

Martens, R. (2006). Úspěšný trenér. Praha: Grada Publishing.

Martínková, I. (2012). How to understand kalokagathia? Tělesná kultura, 35(1), 93-105.

Mechikoff, R. A. (2010). A history and philosophy of sport and physical education: From ancient civilizations to the modern world. New York: McGraw-Hill.

Miller, S. G. (2006). Ancient Greek athletics. New Haven: Yale University Press.

Nařizení vlády č. 222/2010 Sb., o katalogu prací ve veřejných službách a správě. (2010).

Nelson, L. J., Cushion, C. J., \& Potrac, P. (2006). Formal, nonformal and informal coach learning: A holistic conceptualisation. Coach, (35), 59-69.

Novák, J. (2017). 230 let od narození Jana Evangelisty Purkyně - před 180 lety položen základ buněčné teorie. Medicina Sportiva Bohemica et Slovaca, 26(4), 197-202. 
84 Olympijská charta. (2016). Lausanne: Mezinárodní olympijský výbor. Dostupné z https: / /www .olympic.cz/upload/files/OLYMPIJSKA-CHARTA-2016.pdf

Petry, K., Froberg, K., \& Madella, A. (2006). Thematic network project AEHESIS: Report of the third year. Cologne: German Sport University Cologne.

Potrac, P., \& Cassidy, T. (2006). The coach as a „more capable other“. In R. L. Jones (Ed.), The sports coach as educator: Re-conceptualising sports coaching (s. 39-50). London: Routledge.

Průcha, J., Walterová, E., \& Mareš, J. (2009). Pedagogický slovník. Praha: Portál.

Rabelais, F. (1968). Gargantua a Pantagruel. Praha: Odeon.

Reverter-Masia, J., Legaz-Arrese, A., Munguía-Izquierdo, D., \& Barbany, J. R. (2008). The conditioning services in elite Spanish clubs of team sports. International Journal of Sports Science \& Coaching, 3(3), 431-443.

Roček, M. (2016). Skupinový trénink v šermu šavlí [Závěrečná práce]. Praha: UK.

Scambler, G. (2005). Sport and society: History, power and culture. Maidenhead: McGraw-Hill Education.

Sekot, A. (2006). K sociálním aspektům profesní pozice trenéra. In Kolektiv autorů, Sborník prací fakulty sportovních studií, I. ročník: Sport jako sociálně-kulturní fenomén (s. 13-30). Brno: MU.

Schierz, M., Thiele, J., \& Fischer, G. (2006). Fallarbeit in der Trainerausbildung: Möglichkeiten und Grenzen einer pädagogischen Professionalisierung. Köln: Sportverlag Strauss.

Strachová, M., \& Grexa, J. (2014). Dějiny sportu. Brno: MU.

Světový antidopingový kodex. (2016). Montreal: Světová antidopingová agentura. Dostupné z http: / /www.msmt.cz/file/40561/

Svoboda, B. (2000). Pedagogika sportu. Praha: Karolinum.

Šíp, R. (Ed.). (2008). Kalokagathia: ideál, nebo flatus vocis? Brno: MU.

The Magglingen declaration. (2000). Dostupné z http://www.icce.ws/_assets/files/documents/Magglingen.pdf

Tomlinson, A. (2010). A dictionary of sports studies. Oxford: Oxford University Press.

Treutlein, G. (2001). Trainerrolle und Professionalisierung. In H. Haag \& A. Hummel (Eds.), Handbuch Sportpädagogik (s. 455-460). Schorndorf: Verlag K. Hofmann.

Trudel, P., \& Gilbert, W. (2006). Coaching and coach education. In D. Kirk, D. Macdonald, \& M. O'Sullivan (Eds.), The handbook of physical education (s. 516-539). London: SAGE.

Wenn, S. R., \& Schaus, G. P. (2007). Onward to the Olympics: Historical perspectives on the Olympic games. Waterloo: Wilfrid Laurier University Press.

Werthner, P., \& Trudel, P. (2006). A new theoretical perspective for understanding how coaches learn to coach. Sport Psychologist, 20(2), 198-212.

Zákon č. 115/2001 Sb., o podpoře sportu, ve znění účinném od 1. 7. 2017.

Zákon č. 440/2015 Z. z., o športe a o zmene a doplnení niektorých zákonov.

Zákon č. 563/2004 Sb., o pedagogických pracovnících a o změně některých zákonů.

Zákon č. 455/1991 Sb., o živnostenském podnikání (živnostenský zákon) ve znění pozdějších úprav.

Zeigler, E. F. (1993). Chivalry's influence on sport and physical training in medieval Europe. Canadian Journal of History of Sport, 24(1), 1-28. 
doc. PhDr. Marcela Janíková, Ph.D. katedra pedagogiky sportu

Fakulta sportovních studií, Masarykova univerzita Kamenice 5, 62500 Brno janikova@fsps.muni.cz

doc. PhDr. Vladimír Jůva, CSc. katedra pedagogiky sportu

Fakulta sportovních studií, Masarykova univerzita Kamenice 5, 62500 Brno juva@fsps.muni.cz

PhDr. Jan Cacek, Ph.D. katedra atletiky, plavání a sportů $v$ prírodě Fakulta sportovních studií, Masarykova univerzita Kamenice 5, 62500 Brno cacek@fsps.muni.cz 